\title{
3: 49686439-49695938
}

National Cancer Institute

\section{Source}

National Cancer Institute. 3: 49686439-49695938. NCI Thesaurus. Code C41701.

Physical location of APEH_Gene 